\title{
Morphometric and Nutrient Content of Endemic Solen sp. (Lorjuk) of Pamekasan Madura
}

\author{
Mirwa Adiprahara Anggarani \\ Department of Chemistry \\ Universitas Negeri Surabaya,Surabaya \\ Indonesia \\ mirwaanggarani@unesa.ac.id
}

\author{
Erlix Rakhmad Purnama \\ Department of Biology \\ Universitas Negeri Surabaya
}

\begin{abstract}
The research was conducted on May to July 2019, in Pamekasan, Madura, East Java, Indonesia. The aim of this study is to know the nutritional content of Solen sp. (Lorjuk) the shellfish which live and consumed by local community in Madura. This is a descriptive quantitative research. Parameters that used in determining the nutritional quality of the shellfish were water content, ash content, protein, fat and carbohydrates using gravimetry methods. The results of laboratory analysis showed that the ash content and carbohydrates were he highest nutritional content of lorjuk/ razor clams (Solen sp.). Nutritional content of Solen sp. (Lorjuk) were ater content of $0.69 \%$; ash content of $25.40 \%$; protein of $2.63 \%$; fat of $1.06 \%$ and carbohydrates of $70.22 \%$. Based on morphometric analysis, the results obtained, length, width, thickness and intact weight of Solen sp. that breed in Pamekasan Madura were $0.56 \mathrm{~cm} ; 0.79$ cm; $0.74 \mathrm{~cm}$; and 2.19 gram.
\end{abstract}

\section{Keywords-Solen sp., morfometric, nutritional content}

\section{INTRODUCTION}

Nutrients are elements contained in foods that provide benefits for health. Each food ingredient has a different nutritional content. Shellfish is one of the marine biota that is rich in nutrients. Some of the nutritional content in shells include protein, fat, carbohydrates and others. Shellfish as a source of animal protein is included in Complete Protein, due to its high essential amino acid levels (85\% - 95\%) [1].

Molusca are potential fishery commodities as candidates for bioactive compounds. Abundant shellfish in Indonesia include razor clams, scallop clams, feather clams, kappah clams, and mangrove clams. Shellfish is one of the most abundant fisheries products in the tropics and is a good and inexpensive source of animal protein for the community. The existence of razor clams (lorjuk) on Madura Island is very abundant, but has not been used optimally. Razor clams have complete nutritional content, including non-essential amino acids namely glutamic acid of $0.959 \%$, aspartic acid of $0.583 \%$ and glycine of $0.391 \%$ [2]. The need for razor clams causes an increase in catching razor clams. The potential of the biodiversity of the razor clams is interesting to be investigated more deeply in view of its ever increasing demand.

Nutrition is a unit that makes up food and building components of the human body. Nutrition analysis includes analysis including water content, ash content, protein, fat and carbohydrate. These substances are needed for growth, maintain and repair body tissues, regulate processes in the body, and provide energy for bodily functions [3].
The main nutritional ingredients of food according to nutrition are:

\section{Water}

Water is an important component in food, which can affect the appearance, texture, and taste of food. Water will also affect the resistance of food to microbial attack (Gafari, 2011).

\section{Protein}

The protein content is very important in the formation of enzymes in the human body, such as the formation of organ and muscle cells, the formation of hormones, repair damaged cells in the body, regulate metabolism, form the immune system and as a source of energy [4].

\section{Fat}

Fat is a more effective source of energy compared to carbohydrates and proteins [3]. A very important function of fat is to provide energy to help meet the body's needs. Based on its weight, the energy obtained from fat is twice as much as carbohydrates or protein.

\section{Carbohydrates}

Carbohydrates have an important role in determining the characteristics of food ingredients, such as taste, color, texture and others. In the natural body, carbohydrates are useful to help metabolize fats and proteins [5].

Natural isolation products from bivalves and gastropods have been used as antioxidants, antibacterial antivirals, antifungal, antibacterial, cytotoxic anticancer and enzyme inhibitors [6]; [7]; [8]. Some secondary metabolites of aquatic organisms show pharmacological activity [9]. Razor clams (Solen sp.), is a bivalvia that is found in Indonesian waters.

Antioxidants are naturally present in food from land and water. Food derived from the molusca group contains many bioactive components that act as antioxidants. Types of mollusks that are known to contain antioxidants include marine leeches, snail ipong ipong [2], papaya snails [10], taiwan snails [11].

As a food source and source of medicinal ingredients, the nutritional content of razor clams needs to be investigated. This study aims to determine the nutritional content of razor clams (Solen sp.) that live and be consumed by people on Madura Island, especially Pamekasan. The 
nutritional content in question namely, ash content, water content, fat content, protein content and carbohydrate content.

\section{MATERIALS AND METHODS}

The study was conducted in May - July 2019 at the Biochemistry Laboratory, Chemistry Department, Faculty of Mathematics and Natural Sciences, Universitas Negeri Surabaya. The main material in this study is the razor clams (Solen sp.) obtained from the waters of Pamekasan Madura with a length of $2-5 \mathrm{~cm}$ and a width of $0.5-1 \mathrm{~cm}$.

\section{Preparation of sample razor clam}

A total of $2 \mathrm{~kg}$ of fresh (wet) razor clams are washed thoroughly and separated between meat and shells. Then each shell and meat is dried with solar heat for 5-7 days until a dry product with a moisture content of less than $12 \%$ is obtained. The shell and the meat of the dry razor clam are blended with a blender until each powder / flour of the shell and the meat of the dry razor clam are obtained. On the other hand, as much as $1 \mathrm{~kg}$ of fresh (wet) razor clams are washed thoroughly then dried in the sun for 5-7 days until a dry razor clam product is obtained with a moisture content of less than $12 \%$. Furthermore, the dried razor clams are blended with a blender until each blade powder / flour is obtained. Thus obtained 3 types of samples, namely, meat powder, shell powder and razor clams. Henceforth, whole meat, shells and razor clams will be called $\mathrm{D}, \mathrm{C}$, and $\mathrm{K}$.

\section{Ash content analysis}

Each sample D, C and $\mathrm{K}$ were taken as much as 2 gr. Then put into a gray cup that has been burned in the furnace and known the weight. The cup containing the sample is put into the furnace at $650^{\circ} \mathrm{C}$ for 1 hour to a constant weight. After the temperature drops $\pm 200{ }^{\circ} \mathrm{C}$, the plates are removed and cooled in a desiccator for 30 minutes, then weighed. Ash content is calculated by the formula:

$$
\text { Total ash content }(\%)=\frac{\text { ash weight }(\mathrm{g})}{\text { sample weight }(g)} \times 100 \%
$$

\section{Water content analysis}

Each sample D, C and $\mathrm{K}$ were taken as much as 2 gr. Then the sample is put into a porcelain cup that has been dried in an oven and its weight is known. Then the cup containing the oven is put in an oven at $100{ }^{\circ} \mathrm{C}$ for 5 hours until the weight is constant. Then the sample is cooled in a desiccator and weighed by weight. Water content is calculated by the formula:

$$
\text { Water content }(\%)=\frac{\text { initial W }(\mathrm{g})-\text { final W }(\mathrm{g})}{(\text { initial } \mathrm{W}(\mathrm{g})} \times 100 \%
$$

\section{Fat content analysis}

Each sample D, C and $\mathrm{K}$ were taken as much as 5 gr. Then wrapped using filter paper and put in a Soxhlet tube. The soxhlet extraction apparatus is assembled with round bottom flasks that have been dried in an oven and their weight is known to contain a solvent. Then extraction is carried out for 5 hours until the circulating solvent is clear. The extracted solution is put into the oven at $100^{\circ} \mathrm{C}$ for 60 minutes or until a constant weight. Then cooled into a desiccator and weighed. Fat content is calculated by the formula:

$$
\text { Fat content }(\%)=\frac{\text { fat weight }(\mathrm{g})}{\text { sample weight }(g)} \times 100 \%
$$

\section{Protein content analysis}

Each sample D, C and $\mathrm{K}$ were taken as much as 0.5 gr. Samples are put into the destruction flask and $10 \mathrm{ml}$ of concentrated sulfuric acid solution is added and installed in the Kjedahl device and the destruction process is carried out until the solution is clear green. Furthermore, the clear green solution is cooled and the result of destruction is transferred to the distillation apparatus by adding $20 \mathrm{ml}$ of concentrated $\mathrm{NaOH}$ solution until the solution is blackish brown. The distillate is then collected in an erlenmeyer that contains $10 \mathrm{ml}$ of $4 \%$ boric acid solution and 2 drops of methyl red and methyl blue indicators. Then the bluish green solution produced by the distillation is titrated with $0.02 \mathrm{~N}$ $\mathrm{HCl}$ solution until it becomes a pink solution. Besides that, an analysis of the blanks was carried out using the same procedure as the sample. Potein content is calculated by the formula:

$$
\begin{aligned}
& \mathrm{N} \text { content }(\%) \\
& =\frac{(\mathrm{ml} \mathrm{HCl}-\mathrm{ml} \text { blank }) \times \mathrm{N} \mathrm{HCl} \times 14.007}{m g \text { sample }} \times 100 \%
\end{aligned}
$$

6. Carbohydrate content analysis

Carbohydrate content in each sample D, C and $\mathrm{K}$ was $100 \%$ reduced by the total ash, water, protein and fat content in each sample.

\section{RESULT AND DISCUSSION}

In this study, the initial activity carried out was sampling razor clams by walking along the beach area in the Pamekasan region. Razor clams or commonly called lorjuk are shells commonly consumed by residents who inhabit Madura Island. Lorjuk is used as a mixture in making Rengginang crackers and daily dishes. Razor clams taken were taken to the Biochemistry Laboratory, Department of Chemistry, FMIPA Unesa to test the nutritional content. The process of testing the nutritional content of shellfish is done by washing the razor clam clean, then dried with the help of sunlight for 5 days to obtain a dry razor clam with a constant weight value. Furthermore, the dried shells are mashed using a blender to obtain a razor clam powder. Furthermore, razor clam powder was analyzed for water, ash, protein, fat and carbohydrate content with 3 repetitions.

Razor clams have bilateral symmetrical characteristics with both long shells and small elongated bodies. One end of his body is pointed like a blade. Greenish yellow shell. The morphological shape of the razor clam can be seen in Figure 1. 


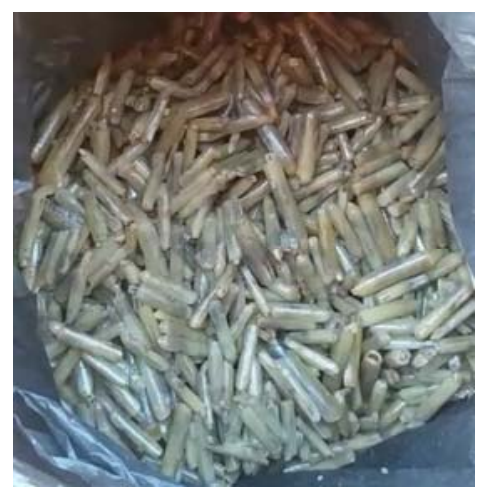

Fig. 1. Morphology of razor clams (Solen sp,) in Pamekasan Madure

Morphometric measurements of the razor clams of Pamekasan Madura were carried out on 40 samples of razor clams. This measurement consists of length, width, thickness, and weight measurements to determine the average length, thickness and weight of razor clams in Pamekasan Madura.

TABLE 1. MORPHOMETRIC RAZOR CLAMS (SOLEN SP.) OF PEMEKASAN MADURA

\begin{tabular}{cc}
\hline Parameters & Average value \\
\hline Length $(\mathrm{cm})$ & $4.56 \pm 0.59$ \\
Width $(\mathrm{cm})$ & $0.79 \pm 0.11$ \\
Thickness $(\mathrm{cm})$ & $0.74 \pm 0.13$ \\
Weight $(\mathrm{gram})$ & $2.19 \pm 0.61$ \\
\hline
\end{tabular}

The chemical composition of the razor clam is obtained through proximate analysis which includes water, ash, protein, fat and carbohydrate content (by difference). The chemical composition of the razor clams results of this study is influenced by habitat and species. These habitats and species affect the metabolism of razor clams, thereby affecting the morphometrics and chemical composition that varies between living species.

TABle 2. PRESENTATION VAlues ( $\%$ ) OF WATER, ASH, PROTEIN, FAT AND CARBOHYDRATE CONTENT OF $100 \mathrm{G}$ OF RAZOR CLAM SAMPLES

\begin{tabular}{ccc}
\hline Nutrient content & Content $(\%)$ & Average $(\%)$ \\
\hline Water & 0.80 & 0.69 \\
& 0.62 & \\
& 0.65 & \\
Ash & 24.98 & 25.40 \\
& 26.01 & \\
& 25.21 & \\
Protein & 2.45 & 2.63 \\
& 2.89 & \\
& 2.55 & \\
Fat & 0.99 & 1.06 \\
& 1.14 & \\
& 1.05 &
\end{tabular}

$\begin{array}{lll}\text { Carbohydrates } & 71.05 & 70.22 \\ & 70.90 & \\ & 68.71 & \end{array}$

Among the five nutritional contents that have been analyzed it is known that carbohydrate content is the largest nutrient content in razor clams. The next biggest nutrient level is ash. The high level of carbohydrate is caused in the process of making razor clams between the meat and the shell is not separated (used together). Razor clams contain very high fiber. The high ash content in the shells results of this study indicate that the razor clams contain minerals that are quite high.

Based on the results of the proximate analysis presented in Table 2, the amount of water content of the razor clams produced in this study is very low, which is below $1 \%$. With this low level, the shelf life of razor clams will be very long, because the probability of microbial contamination in the preparation is very low. With this very low water content, it is very unlikely that microbes can multiply in it.

The ash content of razor clams produced from this research was $25.40 \%$. The ash content of razor clams produced from this study was low when compared to other types of shells, such as blood shells (Anadara granosa), which amounted to $2.24 \%$ [2]. High or low ash content is influenced by habitat (environment). Each aquatic environment can provide different mineral intake for aquatic organisms that live in it. Each individual organism also has different abilities in regulating and absorbing inorganic components, so this will later influence the ash content in each material [12].

The protein content of razor clams powder produced from this study was $2.63 \%$. The protein content of this shellfish powder is lower than other types of shells, namely blood shells (Anadara granosa) which is $19.48 \%$. The high level of protein in the shellfish is influenced by the habitat from which the shells originate. The chemical composition of shellfish varies greatly depending on species, sex, age and habitat [2].

The fat content of razor clams results of this study was $1.06 \%$. high and low fat content is influenced by habitat and shellfish species. Fat on the body of living things is stored at $45 \%$ around the organs and abdominal cavity. In animal body fat is stored under the skin and around certain organs, for example fat around the kidneys [13].

Carbohydrate content of razor clams results of this study were calculated based on the method by difference which is equal to $70.22 \%$. Carbohydrates in fishery products are generally found in the form of glycogen. The glycogen content in fishery products is $1 \%$ in fish, $1 \%$ in crustaceans, and $1-8 \%$ in shellfish [14]. 


\section{CONCLUSION}

Razor clams that breed in Pamekasan Madura have morphometric, that is, weight, length, width, thickness and an average total weight of, $4.56 \mathrm{~cm} ; 0.79 \mathrm{~cm} ; 0.74 \mathrm{~cm}$; and 2.19 gram. Based on proximate analysis, razor clams that live in the Pamekasan Madura, have a chemical composition, namely water content, ash, protein, fat and carbohydrates in a row by $0.69 \% ; 25.40 \% ; 2.63 \% ; 1.06 \%$ and $70.22 \%$. High and low chemical composition of the razor clams is influenced by habitat and species.

\section{ACKNOWLEDGMENT}

Thank to Indonesian Government for the support for this research.

\section{REFERENCES}

[1] E. Supriyantini, Kandungan Asam Lemak Omega 3 (Asam Linolenat) pada Kerang Totok Polimesoda yang Diberi Pakan Tetraselmis Chui dan Skeletonema (Omega 3 Fatty Acid Content (Linolenic Acid) in Polimesoda Totok Shells Given Chui Tetraselmis Feed and Skeletonema), Skripsi. Fakultas Perikanan dan Ilmu Kelautan. IPB. Bogor, 2007

[2] L. Nurjanah, Izzati \& A. Abdullah, Aktivitas antioksidan dan komponen biokatif Kerang Pisau (Solen $s p$ ) (Antioxidant activity and biocative components of Shellfish (Solen sp).). J. Pengolahan Hasil Perikanan Indonesia, 2011, XVI(3):119-124

[3] F. G. Winarno, Pangan Gizi, Teknologi dan Konsumen (Nutrition, Technology and Consumer Food). Gramedia Pustaka Utama. Jakarta, 1993

[4] A. Gafari, Karaketristik Asam Lemak dan Daging Keong Macan (Babylonia spirata), Kerang Tahu (Meretrix meretrix) dan Kerang Salju (Pholas dactylus)( Karaketristik Fatty Acid and Tiger Snail Meat (Babylonia spirata), Tofu Shellfish (Meretrix meretrix) and Snow Shells (Pholas dactylus)), Skripsi, FPIK IPB, Bogor, 2011
[5] Antoni, Fluktuasi Kandungan Proksimat Kerang Bulu (Anadara inflata R.) (Fluctuations in the Proximate Content of Feather Shells (Anadara inflata R.)), IPB, Bogor, 2010

[6] M., B. Tadesse, M.B. Gulliksen, O.B. Strim, Styrvoid, \& T. Haug, Screening for antibacterial and antifungal activities in marine benthic invertebrates from northern Norway. J. Invertebrate Pathology, 2008, 99: 286-293

[7] D. N. Defer, Bourgougnon, \& Y. Fleury, Screening for antibacterial and antiviral activities in three bivalve and two gastropod marine molluscs (Screening for antibacterial and antiviral activities in three bivalves and two gastropod marine molluscs.). J. Aquaculture, 2009, 293: $1-7$

[8] D.Y. Zhou, L. Zhu, H. T. Qiao, D. M. Wu, J. F. Li, Yang, \& Y. Murata, In vitro antioxidant activity of enzymatic hydrolysates prepared from abalone (Haliotis discus hannai Ino) viscera, Food and Bioproducts Processing, in press, 2011

[9] D. Pringgenies, Karakteristik senyawa bioaktif bakteri simbion moluska dengan GC-MS (Characteristics of mollusk symbiotic bacterial bioactive compounds with GC-MS). J. Ilmu dan teknologi Kelautan Tropis, 2010, 2(2): 34-40

[10] R. Suwandi, Nurjanah, \& F. Naryuningtias, Aktivitas antioksidan dan komponen bioaktif dari keong papaya (Melos sp) (Antioxidant activity and bioactive components of papaya snail (Melos sp)), Akuatik, 2010, 4(2):16-20

[11] E. Salamah, E. Ayuningrat, \& S. Purwaningsih, Penapisan awal komponen bioaktif dari Kijing Taiwan (Anadonta woodiana Lea.) sebagai senyawa antioksidan (Initial screening of bioactive components from Taiwan Kijing (Anadonta woodiana Lea.) As an antioxidant compound), Buletin Teknologi Hasil Perikanan, 2008, 11(2):119-132

[12] S. Rusyadi, Karakter Gizi dan Potensi Pengembangan Kerang Pisau (Solen sp.) (Nutrition Characteristics and Potential Development of Knife Shells (Solen sp.)), Skripsi, Fakultas Perikanan dan Ilmu Kelautan. Universitas Muhamadiyah, Malang, 2006

[13] P.M . Gaman, and K.B Sherrington, Ilmu Pangan (Ilmu Pangan), Pengantar Ilmu Pangan Nutrisi dan Mikrobiologi, Yogyakarta: UGM Press, 1994

[14] M. Okuzumi, dan T. Fujii, Nutritional and Functional Properties of Squid and Cuttlefish, National Cooperative Association of Squid Processor, Japan, 2000 